\begin{tabular}{cc}
\hline EJEM & $\begin{array}{c}\text { ECONOMIC JOURNAL OF } \\
\text { EMERGING MARKETS } \\
\text { Econ.J. Emerg. Mark. }\end{array}$ \\
\hline
\end{tabular}

\title{
Flypaper effect at the local governments: an empirical analysis for Aceh Province
}

\author{
Irham Iskandar $^{1}$ \\ ${ }^{1}$ Development Planning Agency (Bappeda), Daerah Istimewa Aceh, Indonesia \\ Email: irhamis@yahoo.com
}

\section{Article Info}

Received : 10 September 2014

Accepted : 2 Maret 2015

Published: 1 April 2015

Keywords:

Flypaper effect, institution,

expenditure, public spending

JEL Classification:

H72, H78, H79

DOI:

http://dx.doi.org/10.20885/ejem .vol7.iss1.art3

\begin{abstract}
The objective of this reseach is to test the phenomenon of flypaper effect in local governments in Aceh Province during 2008 to 2012. The research used panel data analysis. Technically, it regresses the independent variables of the local owned revenue and unconditional grants on dependent variable of public spending where the institutions as a moderating variable. The flypaper effect was found in the case of public and infrastructure expenditures. The study also found that the institution is capable to reduce the use of unconditional grants. It means that by the role of institution the local owned revenue can be optimized.
\end{abstract}

\begin{abstract}
Abstrak
Tujuan dari penelitian ini adalah untuk menguji apakah fenomena flypaper effect terjadi di pemerintah daerah kabupaten/kota di Provinsi Aceh selama tahun 2008 sampai 2012. Metode analisis yang digunakan adalah regresi model data panel. Secara teknis penelitian ini meregres variabel independen yaitu Pendapatan Asli Daerah dan dana transfer terhadap variabel dependen yaitu belanja publik dan infrastruktur dimana variable kelembagaan digunakan sebagai variabel moderasi. Efek flypaper ditemukan dalam kasus pengeluaran public maupun infrastruktur. Studi ini juga menemukan bahwa factor kelembagaan mampu mengurangi penggunaan dana transfer. Jadi peran kelembagaan dapat diharapkan untuk berperan dalam mengoptimalkan penerimaan Pendapatan Asli Daerah.
\end{abstract}

\section{Introduction}

The government of Indonesia effectively implemented Law No. 25 of 1999 on Financial Balance between Central and Regional Governments in 2001. The enforcement of the law led Indonesia into a new era in fiscal decentralization and structural transformations, where in the earlier era the management of regional finance was more centralistic. Now it is more decentralized. The goal of this change is to create and develop a public system that is capable for providing more effective and efficient local public goods and services by steadily mantaining the macroeconomic stability. It is realized by transferring some authorities to make spending and to collect taxes to local governments and by providing grants in form of transfers from central government to local governments.

The sources of funding for local government spending consists of PAD (Local Owned Revenue), balancing fund, and other legal incomes. The PAD consists of local taxes, local user charges and other legal revenues. Balancing fund is a local funding sourced from national budget that is consisting of Sharing Fund (DBH), General Allocation Fund (DAU), and Special Allocation Fund (DAK). For Aceh Province, as shown on Table 1, during 2008-2012 it can be seen that the revenues of Aceh Provice sourcing from unconditional grant was increasing as compared to the PAD. It means that Aceh's local expenditures were predominantly influenced by the contribution of unconditional grant. Thus, to enhance the 
capacity of local governments in funding their expenditure, it urgently need to strenghten the local governments' capacity in generating income from taxations.

Table 1: Share of Provincial Unconditional Grant and PAD of the Total Local Expenditures

\begin{tabular}{cccc}
\hline & \multicolumn{2}{c}{ Unconditional Grant } & \\
\cline { 2 - 3 } Year & DAU & DBH & PAD \\
\hline 2008 & 46.87 & 35.55 & 12.63 \\
2009 & 77.93 & 24.44 & 13.97 \\
2010 & 62.08 & 22.66 & 12.94 \\
2011 & 77.02 & 24.42 & 11.02 \\
2012 & 81.24 & 14.00 & 10.33 \\
\hline $\begin{array}{l}\text { Source: Directorate } \\
\text { 2012 }\end{array}$
\end{tabular}

The predominance of transfer role relative to PAD in funding the local government expenditures had created such highly dependency of local government to this transfer fund. International empirical evidences show that the high dependence on transfer were negatively related to the outcome of the local government. It suggests that local governments should be more wise in their expenditures sourcing from their local owned revenue rather than sourcing from the intergovernemntal transfer fund (grant) from the central government(Mello and Barenstrei, 2001).

Flypaper effect is phenomenon to describe when a dollar of exogenous intergovernmental fiscal transfer leads to significantly greater public spending than an equivalent dollar of citizen income: money sticks where it hits (Inman, 2008). Some other empirical studies of flypaper effect were conducted, e.g., Deller et. al., (2007) and Deller and Maher (2005) in America, Sagbas and Saruç (2004) in Turkey.

Interestingly, however, a research by Maimunah and Akbar (2008) suggested that flypaper effect has been disclosed not only in local governments with lower PAD but also it happened in the local with higher PAD. Some of them wera found in some districts/municipalities in Sumatra. It indicates that there are stronger factors such as politics in addition to other economic reasons (Courant et al., 1979). The political factor in this case is local economic governance (institution) that greatly cause the occurrence of flypaper effect. Bailey and Stephen (1998) claimed that interest groups, rather than voters, are the major players in budgeting. The powers of pressure groups certainly vary from one program to another and thus the sizes of flypaper effect equally vary in accordance with the categories of expenditures.

The basis of theoretical rationale was on flypaper effect. The flypaper effect phenomenon could be described as follows: a \$1 increase in local owned revenue income should has the same impact on public spending as receiving $\$ 1$ in form of general-purposed transfer. In fact, however, all empirical studies show that the $\$ 1$ received by communities in a form of generalpurposed transfer tends to be used to increase local spending by increasing local owned revenue incomes of more than $\$ 1$. Budget fund tends to stick where it is spent for the first time (money "sticks where it hits"), causing the part that is left for actually smaller tax relief than expected (Boadway and Shah, 2009).

According to literature, there are two explanations for flypaper effect that rely on public choice reasoning, these are bureaucratic model and fiscal illusion. $\mathrm{Bu}-$ reaucratic model suggests that flypaper effect is due to the behavior of bureaucrats that have more freedom to spend transfer funds than to raise taxes. McGuire (in Kuncoro, 2007) labels it as politician greed. Therefore, flypaper effect occurs due to the superior knowledge of bureaucrat on transfer funds. The more information that bureaucrats have means that they may give more expenditures.

On the other side, fiscal illusion model bases its study on the viewpoint of communities who have limited information 
on their regional government budget. Fillimon et. al (1982) developed a hypothesis of fiscal illusion in a context of community's lack of knowledge on the amount of transfer funds received by their local government. In this case, regional governments hide the amount of transfer funds they received from the central government and then they spent them to top level expenditures that the community wants.

Political economy literatures dealing with governance are still in a process toward achieving a mutual agreement or consensus. Generally, governance is meant as traditions and institutions that decide how policies are implemented in a country (Kaufmann et. al., 2000). Weiss (2005) said that governance is related to strategies, processes, methods, and mechanisms in governing a country and fulfilling public demands and interests. Weiss maintained that good governance is related to democracy and fulfillment of civil rights, transparency, rule of law, and efficient public services. Governance also involves the interactions of public and private institutions with community. Likewise, Chibba (2009) explained that governance issues are part of people that have been integrated since the onset of civilization, and it particularly upholds certain values, ethics, and prevailing rules, and justice to be enforced, and related to how people is governed and who shall hold powers and authorities.

Moreover, North (1981) stated that institutions are community's rule of game or, formally, the constraints occurring humanly that create human interactions. The constraints is affected by force (North, 1990). The force is intended for the economic actors to accept the rule of game. Economists have developed North's idea in order to create a drive for economic growth by using different perspectives. The cores of their goal are the same, e.g., to reduce uncertainty and enhance efficiency. New political economy, for example, resists the importance of structure adjusting programs by removing rent-seeking and corruption motives (Kuncoro, 2012).

Literatures specifically deal with the relationship between institution and flypaper effect are still lacking. Bailey and Stephen developed a model where interest groups, not voters, are the key player in budgeting. The political powers of pressure groups certainly vary from one program to another, and thus the sizes of flypaper effect vary with the categories of expenditures. For Oates (1988), the political powers that emerge in budgeting processes are already sufficient to meet the theoretical norm for an occurrence of flypaper effect. Deller and Maher(2005) studied the categories of public expenditures with a focus on the occurrence of flypaper effect and found that the effect of unconditional grant in the categories of expenditures is greater on nonessential needs or luxury needs such as parks and recreations, culture and educational services rather than on essential or normal needs such as security (police) and fire protection.

Local owned revenue (PAD) is the own source of local revenues that should be constantly increased to be capable of bearing a part of expenditure burden required for implementing governmental affairs and development activities. It is expected to be steadily increasing year by year so that the self-sufficiency of broad, real, and responsible regional autonomy can be realized. The key characteristics of a local government that is capable in implementing its autonomy may be characterized by regional financial capacity and dependency to central aid.

Based on some empirical studies related to flypaper effect and their model, it could be seen as follows:

1. Deller et. al. (2007) conducted a study of 581 cities and villages in Wisconsin by using a cross section for a time period of 1987-2000 and used the following model:

PCE $=\alpha_{0}+\alpha_{1}$ SSRPC $+\alpha_{2}$ PCI + e where, PCE is regional expenditures, SSRPC is (interregional revenue shar- 
ing), and PCI is regional revenues. The result proved the occurrence of flypaper effect.

2. Deller and Maher (2005) conducted a study of 572 cities in Wisconsin, including towns and villages, by using a cross section for a time period of 19982000. They invented and used the following model:

$\mathrm{PCE}=\alpha_{0}+\alpha_{1} \mathrm{SSRPC}+\alpha_{2} \mathrm{PCI}+\mathrm{e}$ where, $\mathrm{PCE}$ is regional expenditures, SSRPC is interregional revenue sharing, and PCI is regional revenues.

3. Sagbas and Saruç (2004) conducted a study of 52 provinces in Turkey by using a panel for a time period of 19951998 and used the following model: $\mathrm{EXP}_{\text {it }}=\mathrm{a}+\beta_{1} \mathrm{TAX}_{1 \mathrm{it}}+\beta_{2} \mathrm{RES}_{2 \mathrm{it}}+\mu_{\text {it }}$ where, EXP is regional expenditures, TAX is regional taxes as regional revenues, and RES ia revenue sharing.

The three models above discovered the greater influences of transfer funds on regional expenditures than that of PAD on regional expenditures. It means that there is flypaper effect. It indicates that regional governments tended to just waiting for the transfer funds (grants) from the central government, and they didn't try optimally to cultivate their potential resources for increasing their PAD.

However, a research by Pramuka (2011) showed the opposite result, i.e., there was no flypaper effect. It means that the allocation funds from central government only served to support regional governments in increasing their PAD. Regional governments should not rely their regional expenditures on general allocation funds which is in line with the goal of the central government grant.

In brief, the framework of thought begins in flypaper effect. Flypaper effect is a condition where the rises in transfer funds tend to stimulate more strongly on spending or expenditures than the comparable rises in revenues. However, experts maintain that institutional factors predominantly result in a flypaper effect. For Oates (1988), institutional powers that emerge in budgeting processes are already sufficient to meet the theoretical norm for an occurrence of flypaper effect. Thus, it can be said that institutions have an influence on the relationship between PAD and unconditional grant after excluding public expenditures and infrastructure expenditures. To be clearer, see Figure 1 below.

Grounded in the framework of thought and the result of empirical studies of earlier researchers, the following hypotheses were proposed: (1) Institutions have influence on the relationships between unconditional grant and public expenditures; (2) Institutions have influence on the relationships between unconditional grant and infrastructure expenditures.

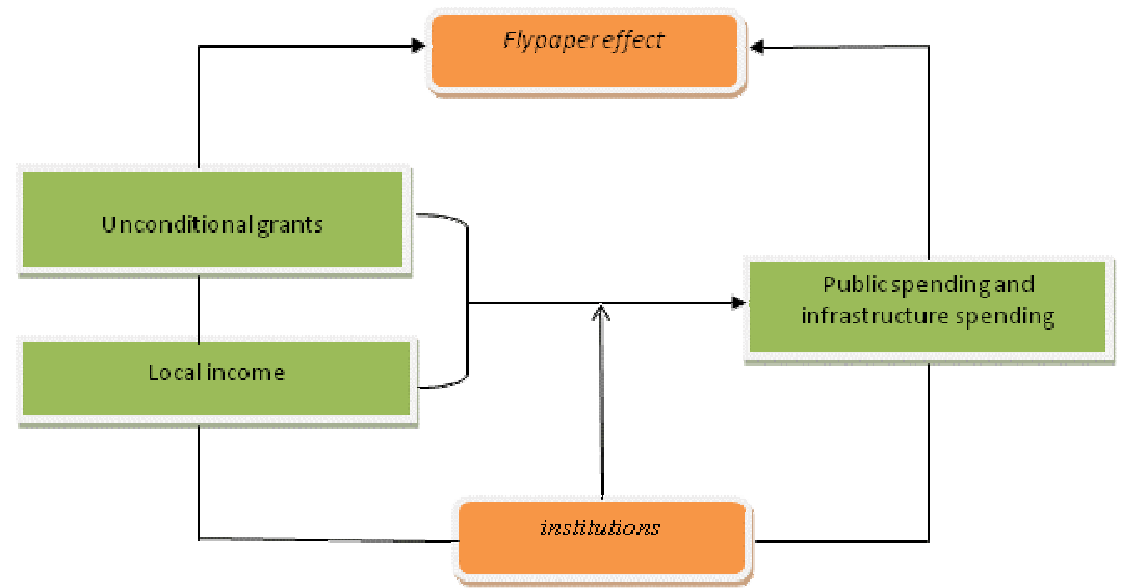

Figure 1: Framework of Analysis 


\section{Research method}

The research population was all districts (18)/municipalities (5) in Aceh Province. The research was conducted by a census method with secondary data in form of time series from 2008-2012, whereas cross section data consisted of the 23 districts and municipalities, so that it pooled the data, i.e., a combination of time series data (2008-2012: 5 years) and cross section data of the 23 districts and municipalities. The process of combining intertemporal data (time series) and interpersonal data (cross section) is called pooling whereas the data generated was called pooled data or panel data. The data collection method used in the research was documentation, where the data was collected by gathering information from official documents published by governments, e.g., Regional Autonomy Implementation Monitoring Committee (KPPOD) and Directorate General of Fiscal Balance (DJPK).

The data analysis method used was a multiple regression analysis method. Multiple regression analysis is an analysis using more than one independent variable. The equation model used was one that analyze the influence of transfer from expenditure side, that is, public expenditures. Next, to test the flypaper effect in the Government of Aceh Province, the study applied the model used by Sagbas and Saruç (2004). The study use a specification of log linear and the model was then specified in form of a model as follows:

$$
\begin{aligned}
\log \mathrm{PB}_{\mathrm{it}}= & \beta_{0}+\beta_{1} \log \mathrm{UG}_{\mathrm{it}}+\beta_{2} \log \mathrm{PAD}_{\mathrm{it}}+ \\
& \beta_{3} \mathrm{Ins}_{\mathrm{it}}+\beta_{4}\left\{\left(\log \mathrm{UG}_{\mathrm{it}}\right) \times\left(\mathrm{Ins}_{\mathrm{it}}\right)\right\} \\
& +\mathrm{e}_{\mathrm{it}}
\end{aligned}
$$

where, $\log \mathrm{PB}$ is $\log$ of public expenditures, $\log$ UG is $\log$ of unconditional grant, log PAD is log of local income, Ins is the institution for which regional economic governance indexes serve as a proxy, and log UGINS is interaction of log UG and Ins. The equation also explains that the variable of $\log$ UG and Ins is a moderating variable that accounts for the influence of the moderating variable of Ins on the relationship between $\log$ UG and log PB.

Likewise, in analyzing the influence of transfer of infrastructure expenditures, the study followed earlier researches such as Deller and Maher (2005). The study was carried out based on a panel data model to examine flypaper effect. In dealing with the issue, the study used a specification of $\log$ linear and then the model was specified in a form of the following model:

$$
\begin{aligned}
\log \mathrm{PI}_{\mathrm{it}}= & \alpha_{0}+\alpha_{1} \log \mathrm{UG}_{\mathrm{it}}+\alpha_{2} \log \mathrm{PAD}_{\mathrm{it}}+ \\
& \alpha_{3} \mathrm{Ins}_{\mathrm{it}}+\alpha_{4}\left\{\left(\log \mathrm{UG}_{\mathrm{it}}\right) \times\left(\mathrm{Ins}_{\mathrm{it}}\right)\right\} \\
& +\mu_{\mathrm{it} .}
\end{aligned}
$$

where, $\log$ PI is $\log$ of infrastructure expenditures, $\log \mathrm{UG}$ is $\log$ of unconditional grant, log PAD is log of local income, Ins is the institution for which regional economic governance indexes serve as a proxy, and log UGINS is interaction of log UG and Ins. The equation also explains that the variable of $\log$ UG and Ins is a moderating variable that accounts for the influence of the moderating variable of Ins on the relationship between $\log \mathrm{UG}$ and $\log$ PI.

Based on equation 1 and 2, it is expected that flypaper effect can be obtained by the value of the coefficient of unconditional grant that is greater than that of the coefficient of revenue. Conversely, if the coefficient of unconditional grant is smaller than that of the coefficient of revenue, flypaper effect doesn't occur.

\section{Result and discussion}

The components of PAD consist of regional tax, local user charges, and other legal PAD. In a framework of the implementation of regional autonomy, PAD is the most strategic indicator in seeing the map of the regional government capacity to finance its development, as well as a picture of the self-sufficiency of a regional government. 
From the four PAD components, regional tax and retribution expectedly play the biggest roles.

The comparison between the total PAD and total regional revenues (TPD) is called fiscal decentralization degree ratio. This ratio indicates the degree of PAD contribution to total regional revenues. The higher the contribution of PAD is, the higher the capacity of regional government is in implementing decentralization. The capacity of local government as computed from the ratio of PAD and total regional revenue could be seen in Table 2 .

Table 2: Fiscal Decentralization Degree of Aceh Province

\begin{tabular}{cc}
\hline Year & The ratio of PAD to TPD \\
\hline 2008 & 3,56 \\
2009 & 3,58 \\
2010 & 6,91 \\
2011 & 5,53 \\
2012 & 6,03 \\
Average & $\mathbf{5 , 1 2}$ \\
\hline
\end{tabular}

The table above shows that the average ratio of PAD and total regional revenue was $5.12 \%$. Though the ratio was constantly fluctuating, regional financial capacity of Aceh Province government was very weak, being in a decentralization degree interval scale of $0.00-10.00$. The reason is that there was a dependence of regional finance on the balance funds from the central government which was ever increasing from year to year. It implies that the government of Aceh Province couldn't yet optimize its own potentials.

In line with the implementation of regional autonomy and fiscal decentralization in 2001, fund transfers from APBN (national budget) to local governments are allocated in form of balance funds. These transfers are aimed at (1) reducing fiscal discrepancy between central and local governments and (2) enhancing the quality of public services in local governments and reducing interregional discrepancies of public services. Relating to this, for the ratio of dependence, i.e., a comparison between the amount of transfer revenues and total regional revenues (Table 3 ).

Table 3: Ratio of Dependence in Aceh Province

\begin{tabular}{lc}
\hline Year & Income transfer to TPD \\
\hline 2008 & 91,32 \\
2009 & 89,87 \\
2010 & 88,36 \\
2011 & 87,38 \\
2012 & 89,38 \\
Average & $\mathbf{8 9 , 2 6}$ \\
\hline
\end{tabular}

Table 3 shows that the transfer revenues from the central government and total regional revenues were slightly fluctuating. The average ratio was $89.26 \%$ indicating that the dependence on transfer funds from the central government was very high. If the percentage is greater than $50.01 \%$ then it indicates that the regional government is still not optimal in utilizing its transfer funds for investment to increase its PAD.

The development of regional expenditures can be seen from a harmoniousness ratio. The ratio indicates the capacity of regional government in prioritizing optimally its fund allocations to public and routine expenditures. The higher the percentage of funds allocated to routine expenditures is, the smaller the percentage of the public expenditures used to provide economic facilities and infrastructures will be. For more detail, see Table.

The table showed that the percentages of public (PB) and operating expenditures (PR) were fluctuating slightly, though there were increases in term of budget. In general, the regional government tended to increase public facilities and infrastructures in attempt to boost the local economy. It could be seen from the percentages of public expenditures that received a larger proportion than the routine expenditures did. 
Table 4: Harmonization Ratio in Aceh Province

\begin{tabular}{ccccc}
\hline Year & Public Expenditure & Percentage & Operating Expenditure & Percentage \\
\hline 2008 & 4.216 .742 & 61,77 & 2.609 .727 & 38,23 \\
2009 & 5.932 .918 & 61,61 & 3.696 .304 & 38,39 \\
2010 & 5.780 .874 & 54,77 & 4.773 .191 & 45,23 \\
2011 & 7.105 .420 & 56,77 & 5.410 .230 & 43,23 \\
2012 & 8.000 .527 & 53,73 & 6.889 .060 & 46,27 \\
\hline
\end{tabular}

Figure 2: An Index of Regional Economic Governance

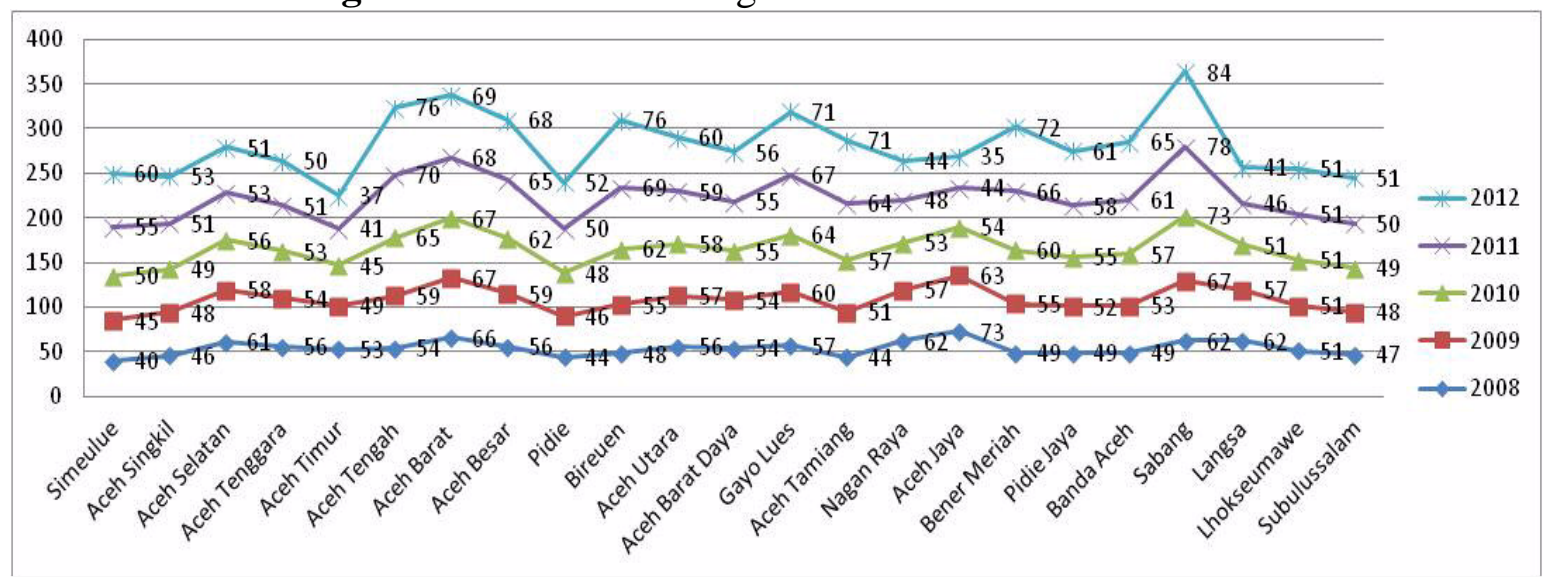

Meanwhile, the institutions from regional economic governance side could be seen on Figure 2. The figure showed that in 2012 Sabang Municipality fell into a category of the best economic governance, i.e., 84, whereas the worst economic governance was Aceh Jaya, 35. KPPOD (2007) identified some constraints such as the barriers that arose from regional government programs in developing private enterprises, land accesses, and legal uncertainty. Moreover, there were still some obstructions in interactions between regional government and entrepreneurs, inefficiency of regional retributions, business license affairs, security and conflict resolution, and the integrity of regents/mayors.

In addition to the result of description as presented above, it also needs to see the result of regression to answer the hypothesis. The result of regression could be seen in Table 5. The result of estimation showed that flypaper effect can be found from the coefficient of unconditional grant that influences significantly to public expenditures, i.e., an increase of 1 percent in unconditional grant cause an increase 0.74 percent in public expenditures, compared to only 0.26 percent in PAD.

Table 5: The result of Estimated Public Expenditures

\begin{tabular}{lccc}
\hline \multicolumn{1}{c}{ Variable } & Coefficient & Std. Error & t-Statistic \\
\hline LOGUG & 0.747266 & 0.084178 & $8.877 .176^{*}$ \\
LOGPAD & 0.265004 & 0.106594 & $2.486 .095^{*}$ \\
INS & 0.023354 & 0.004478 & $5.215 .335^{*}$ \\
LUGUGINS & -0.003882 & 0.00959 & $-4.050 .162^{*}$ \\
R-square & 0,730025 & & \\
\hline
\end{tabular}

Note: * significant at 5\% significance level 
Table 6: The result of Estimated Infrastructure Expenditures

\begin{tabular}{cccc}
\hline Variable & Coefficient & Std. Error & t-Statistic \\
\hline LOGUG & 0.488666 & 0.025776 & 18.95844 \\
LOGPAD & 0.386639 & 0.032805 & 11.78612 \\
INS & 0.066066 & 0.004979 & 13.26916 \\
LUGUGINS & -0.010870 & 0.00099 & -10.97928 \\
R-square & 0.483335 & & \\
\hline
\end{tabular}

Note: $*$ significant at $5 \%$ significance level

In addition, institutions influenced the increases in public expenditures. It could be seen when the variable was moderated, the result shows that institutions were capable of reducing the use of unconditional grant by 0.743384 percent, due to the role the institutions played in optimizing PAD. However, this decrease in transfer was still smaller. Therefore, in the future, institutions should be optimized further by various pro-growth programs and activities, such as by developing regional special products.

The estimation result on the Table 6 above indicated that flypaper effect can be found from the amount of unconditional grant that influences significantly infrastructure expenditures, i.e., an increase of 1 percent in unconditional grant caused an increase 0.48 percent in infrastructure expenditures, compared to 0.38 percent in PAD.

In addition, institutions influenced the increases in infrastructure expenditures. It could be seen when the variable was moderated, the result showed that institutions were capable of reducing the use of unconditional grant by 0.477796 percent, due to the role the institutions played in optimizing PAD. However, this decrease in transfer was still small. Therefore, in the future, institutions should be optimized further by various pro-growth programs and activities, such as by developing regional special products.

\section{Conclusion}

Flypaper effect has an impact on the increases in public expenditures and in other public sectors such as infrastructure ex- penditures, because regional governments responded more to transfer funds than to PAD in increasing their expenditures. In addition, institutional factors have some influence on the increases in public expenditures. It could be seen when the variable was moderated, the result of which showed that institutions were capable of reducing the use of unconditional grant, due to the role the institutions played in optimizing PAD. Based on the research findings the local governments should allocate their budgets as efficient as possible to the programs and activities in the sectors that based on the public or community interests so that the regional government can increase their PAD.

\section{References}

Anonim, (1999), Law of the Republic of Indonesia Number 25 of 1999 on Revenue Sharing between Central and Local Government

Bailey, S.J. and Connolly, S. (1998), “ The flypaper effect: identifying areas for further research," Public Choice, 95(3-4), 335-361.

Boadway, R. and Shah, A. (2009), Fiscal federalism: principles and practices of multiorder governance. Published in the United States of America by Cambridge University Press, New York.

Chibba, M. (2009), "Governance and development, the current role of theory, policy and practice", World Economics , 10(2), 78-108. 
Courant, P. N., Gramlich, E. M. and Rubinfeld, D. L. (1979), “The stimulative effects of intergovernmental grants: or why money sticks where it hits", in Fiscal Federalism and Grants-inAid, Mieszkowski, $\mathrm{P}$ and W. $\mathrm{H}$. Oakland (editors), 5-21, Washington D.C.: The Urban Institute.

Deller, S. and Maher, C.S. (2005), "Municipal expenditures with a focus on the flypaper effect," Public Budgeting and Finance, 5(3), 7390.

Deller, S., Maher, C.S. and Lledo, V. (2007), "Wisconsin local government, state share revenue and the illusive flypaper effect," Journal of Public Budgeting, Accounting dan Financial Management, 19 (2), 200-220.

Fillimon, R., Romer, T. and Rosenthal, H. (1982), "Asymmetric information and agenda control", Journal of Public Economics, 17(2), 51-70.

Inman, R.P. (2008), "The flypaper effect," NBER Working Paper, No. 14579

Kaufmann, D., Kraay, A. and ZoidoLobaton, P. (2000), "Governance matters: from measurement to action," Finance and Development , 37(2), 10-13.

KPPOD (2007), Local economic governance and Nias, Research Report KPPOD dan The Asia Foundation, Jakarta: Ministry of KPDT.

Kuncoro, H. (2007), "Phenomena flypaper effect at financial performance of local government and districts in Indonesia," National Symposium Accounting X, Padang.

Kuncoro, H. (2012), "Does regional economic governance in Indonesia have increased?" Bulletin of Mone- tary Economics and Banking, 15(1), 83-106.

Maimunah, M. and Akbar, R. (2008), "Flypaper effect on the General Allocation Fund (DAU) and local income PAD) of the at regional expenditures of District / Town on the island of Sumatra," Indonesian Journal of Accounting Research, 1(1), 37-51.

Mello, L.D. and Barenstrein, M. (2001), "Fiscal decentralization and governance: a cross-country analysis," IMF Working Paper WP/01/71.

North, D.C. (1981), Structure and change in economic history, New York, W.W. Norton.

North, D.C. (1990), Institutions, institutional change, and economic performance, Cambridge University Press, UK.

Oates, W.E. (1988), “On the nature and measurement of fiscal illusion. A survey", In: Brennan, G. et al (eds), Taxation and fiscal federalism: Essay in honor of Russell Mathews, Canberra: Australian National University Press, 65-82

Pramuka, B.A (2011), Flypaper effect at local government expenditures in Java, Jurnal Ekonomi Pembangunan, 11(1), 1-12

Sagbas, I. and Saruç, N.T. (2004), "Intergovernmental transfers and the flypaper effect in Turkey," Turkish Studies, 5(2), 79-92.

Weiss, T.G. (2005), "Governance, good governance, and global governance: conceptual and actual challenges," in Wilkinson, R (Ed.), the Global Governance Reader, New York: Routledge. 